\title{
Cyanobacteria and microcystins in lake Furnas (S. Miguel island-Azores)
}

\author{
Maria C. R. Santos ${ }^{1, *}$, Helena Muelle ${ }^{1}$ and Dina M. D. Pacheco ${ }^{2}$ \\ 1 Departamento de Ciências e Engenharia do Ambiente, Faculdade de Ciências e Tecnologia (FCT), Universi- \\ dade Nova de Lisboa, 2829-516 Caparica, Portugal. \\ ${ }^{2}$ Secretaria Regional do Ambiente, Governo Regional dos Açores, Avenida Antero de Quental-Edifício dos \\ CTT $2^{\circ}$ A, 9 500-160 Ponta Delgada, Portugal.
}

* Corresponding author: mcrs@fct.unl.pt

Received: 9/11/2010 Accepted: 9/9/2011

\begin{abstract}
Cyanobacteria and microcystins in lake Furnas (S. Miguel Island-Azores)

This study investigated the changes in the cyanobacterial population and quantified the occurrence of microcystins in Lake Furnas during the first decade of the $21^{\text {st }}$ century.

The eutrophication of Lake Furnas has been recognized since the 1980s. The lake's phytoplankton population increased over the years in relation to this process of nutrient enrichment. Cyanobacteria began to dominate the phytoplankton and blooms of greater than $20 \cdot 10^{3}$ cells/ml occurred. After 2004, cyanobacterial blooms occurred regularly in the lake throughout the year. From 2000 through 2009, 30 blooms were detected. Of these blooms, 13 were dominated by Microcystis aeruginosa and 11 by Woronichinia naegeliana. In the other 6 blooms, the dominant cyanobacteria were Microcystis spp., Anabaena spp., Aphanocapsa spp. and Coelosphaerium kuetzingianum. A number of blooms involved more than 2 species simultaneously. The highest cell density $\left(12.3 \cdot 10^{6}\right.$ cells $\left./ \mathrm{ml}\right)$ occurred during winter 2007 . The predominant species in this bloom were $M$. aeruginosa $\left(11.9 \cdot 10^{6}\right.$ cells $\left./ \mathrm{ml}\right)$ and $W$. naegeliana $\left(83.8 \cdot 10^{3}\right.$ cells $\left./ \mathrm{ml}\right)$.

Because almost all of the cyanobacteria cited were considered toxin producers, a search for microcystins, the hepatotoxins most often found in freshwaters, was initiated in 2001. Samples were collected at four depths: surface, $2.5 \mathrm{~m}, 5.0 \mathrm{~m}$ and 0.5 $\mathrm{m}$ above the sediments.

From 2001 through 2009, soluble microcystins were detected six times during the summer, four times during the winter and autumn and three times during the spring (25\% of 129 samples). The average concentrations of soluble microcystins in the water column ranged from $0.1 \mu \mathrm{g} / \mathrm{l}$ to $0.5 \mu \mathrm{g} / \mathrm{l}$. Intracellular microcystins were detected in $84 \%$ of the samples. All samples collected after 2004 contained these cyanotoxins. The average concentrations of intracellular microcystins in the water column ranged from $0.1 \mu \mathrm{g} / \mathrm{l}$ to $11.2 \mu \mathrm{g} / \mathrm{l}$. The highest value $(154.5 \mu \mathrm{g} / \mathrm{l})$ was found in a water sample collected from the lake surface during the winter of 2009 , during a bloom dominated by $W$. naegeliana. The amounts of microcystins produced by cyanobacteria, expressed on a seston dry weight basis, varied between $24 \mathrm{mg} / \mathrm{kg}$ and $9737 \mathrm{mg} / \mathrm{kg}$ and showed an increase in 2008 and 2009. The concentrations of microcystins in samples from $M$. aeruginosa blooms ranged from $86 \mathrm{mg} / \mathrm{kg}$ to 1171 $\mathrm{mg} / \mathrm{kg}$ and the highest values were recorded during the spring and summer of 2008.
\end{abstract}

Key words: Water quality, cyanobacteria, blooms, microcystins.

\section{RESUMEN}

Cianobacterias y microcistinas en la laguna Furnas (isla de S. Miguel-Azores)

Este estudio presenta la variación de la población de cianobacterias y la cuantificación de microcistinas en la Laguna Furnas en la primera década del siglo 21.

La eutrofización de la Laguna Furnas había sido señalada desde los años ochenta del siglo pasado. Debido a este proceso de enriquecimiento en nutrientes, la población de fitoplancton aumentó a lo largo de los años, las cianobacterias se volvieron dominantes y surgieron blooms (más de $20 \cdot 10^{3}$ células $/ \mathrm{ml}$ ). Después del 2004, los blooms de cianobacterias fueron permanentes en la laguna. 
De 2000 a 2009, se detectaron 30 blooms, 13 dominados por Microcystis aeruginosa y 11 por Woronichinia naegeliana. En los 6 restantes, las cianobacterias dominantes fueron Microcystis spp., Anabaena spp., Aphanocapsa spp. y Coelosphaerium kuetzingianum. A recesen algunas ocasiones, existieron más de dos especies en la fase de Bloom al mismo tiempo. La densidad celular más alta $\left(12.3 \cdot 10^{6}\right.$ células $\left./ \mathrm{ml}\right)$ tuvo lugar en el invierno de 2007 , siendo M. aeruginosa $\left(11.9 \cdot 10^{6}\right.$ células $\left./ \mathrm{ml}\right)$ y la $\mathrm{W}$. naegeliana $\left(83.8 \cdot 10^{3}\right.$ células $\left./ \mathrm{ml}\right)$ las especies predominantes.

A partir de 2001 y una vez que casi todas las cianobacterias mencionadas fueron consideradas como productoras de toxinas, se inició la búsqueda de microcistinas, concretamente las hepatotoxinas ya que son las más frecuentes en aguas dulces. Las muestras se tomaron en cuatro profundidades: superficie, $2.5 \mathrm{~m}, 5.0 \mathrm{~m}$ y $0.5 \mathrm{~m}$ por cima del sedimento.

De 2001 a 2009, fueron detectadas microcistinas solubles seis veces en verano, cuatro veces en invierno y otoño y tres veces en primavera (25\% de 129 muestras). Sus concentraciones medias en la columna de agua variaron desde $0.1 \mu \mathrm{g} / \mathrm{l}$ hasta $0.5 \mu \mathrm{g} / \mathrm{l}$. Fueron detectadas microcistinas intracelulares en el $84 \%$ de las muestras y en todas las recogidas después del 2004. Sus concentraciones medias en la columna de agua variaron desde $0.1 \mu \mathrm{g} / \mathrm{l}$ hasta $11.2 \mu \mathrm{g} / \mathrm{l}$. El valor más alto (154.5 $\mu \mathrm{g} / \mathrm{l}$ ) fue encontrado en una muestra recogida en la superficie durante el invierno de 2009, mientras ocurría un bloom dominado por $\mathrm{W}$. naegeliana. Las cantidades de microcistinas producidas por las cianobacterias, expresadas en base de peso seco del seston, variaron entre $24 \mathrm{mg} / \mathrm{kg}$ y $9737 \mathrm{mg} / \mathrm{kg}$ y mostraron un aumento en los años 2008 y 2009. Las concentraciones en muestras de blooms de M. aeruginosa variaron desde $86 \mathrm{mg} / \mathrm{kg}$ hasta $1171 \mathrm{mg} / \mathrm{kg}$ y los valores más altos fueron registrados en primavera $y$ verano de 2008 .

Palabras clave: Calidad del agua, cianobacterias, floraciones algales, microcistinas.

\section{INTRODUCTION}

Lake Furnas is located in the eastern region of S. Miguel island, the largest island in the Archipelago of the Azores $\left(37^{\circ} 46^{\prime} \mathrm{N} ; 25^{\circ} 19^{\prime} \mathrm{W}\right)$. It is a warm monomictic lake and is located in the caldera of Furnas volcano. The surface of the lake is $280 \mathrm{~m}$ above sea level. The lake has an area of $1.9 \mathrm{~km}^{2}$ and a maximum depth of $12 \mathrm{~m}$. Over the past 30 years, a local meteorological station recorded average air temperatures in this region ranging from $12{ }^{\circ} \mathrm{C}$ in winter to $19{ }^{\circ} \mathrm{C}$ in summer (unpublished data supplied by Regional Environmental Secretary). The daily thermal amplitude was very narrow. The monthly average precipitation ranged from $961 / \mathrm{m}^{2}$ in summer to $229 \mathrm{l} / \mathrm{m}^{2}$ in winter, with a daily maximum of $802 \mathrm{l} / \mathrm{m}^{2}$. The hydrological basin has an area of $13 \mathrm{~km}^{2}$ and a perimeter of $14 \mathrm{~km}$. The total runoff from the drainage basin to the lake is approximately $22.2 \cdot 10^{6} \mathrm{~m}^{3} /$ year and flows mainly from three small torrential streams.

The eutrophication of Lake Furnas, due to nutrient enrichment enhanced by human agricultural activities, began to be recognised during the 1980s. As a result of the first monitoring programme conducted in this lake in 1988/89, the lake was classified as eutrophic (average Carlson's TSI for chlorophyll $a=66$ ). Later studies concluded that Lake Furnas was receiving nutrient loadings eleven and nine times higher than the maximum permissible loadings of nitrogen and phosphorus, respectively 17.0-67.0 g N/ $\mathrm{m}^{2}$. year and $0.86-1.61 \mathrm{~g} \mathrm{P} / \mathrm{m}^{2}$. year. These nutrient inputs explained the trophic state of the lake.

In $1988 / 89$, the phytoplankton densities in Lake Furnas ranged from $6.21 \cdot 10^{3}$ cells $/ \mathrm{ml}$ to $9.34 \cdot 10^{3}$ cells $/ \mathrm{ml}$. The phytoplankton populations were dominated by Bacillariophyceae during the winter, Chlorophyceae during the spring and Cyanobacteria during the autumn and summer (primarily Aphanizomenon flos-aquae$3.09 \cdot 10^{3}$ cells $/ \mathrm{ml}$ to $5.96 \cdot 10^{3}$ cells $/ \mathrm{ml}$ ). A $M i$ crocystis sp. was also found, but its maximum count was $0.11 \cdot 10^{3}$ cells $/ \mathrm{ml}$ (Rodrigues et al., 1993). From 1992 to 1996, phytoplankton densities varied between $0.83 \cdot 10^{3}$ cells $/ \mathrm{ml}$ and $13.0 \cdot 10^{3}$ cells $/ \mathrm{ml}$, and Bacillariophyceae still dominated during the winter, Chlorophyceae during the spring and cyanobacteria during the sum- 
mer and autumn. The percentages of cyanobacteria during this period ranged from 0 to $93 \%$. The most abundant species found was again Aphanizomenon flos-aquae, with a maximum density of $12.1 \cdot 10^{3}$ cells/ml (INOVA, 1996-unpublished data). In 1997 and 1998, the maximum phytoplankton count increased to $27.9 \cdot 10^{3}$ cells $/ \mathrm{ml}$, but cyanobacteria represented only $35 \%$ of the total phytoplankton. Among the cyanobacteria, Aphanizomenon flos-aquae almost disappeared, Anabaena sp. increased to a maximum of $0.78 \cdot 10^{3}$ cells $/ \mathrm{ml}$ and Microcystis aeruginosa increased to $8.40 \cdot 10^{3}$ cells/ml during autumn 1997 and to $9.86 \cdot 10^{3}$ cells/ml during winter 1998. Chlorophyceae were dominant during the remainder of $1997 / 98$. Their densities ranged from $0.97 \cdot 10^{3}$ cells $/ \mathrm{ml}$ to $6.23 \cdot 10^{3}$ cells $/ \mathrm{ml}$ (INOVA, 1998-unpublished data). These findings are normal under eutrophic conditions. In eutrophic waters, cyanobacteria often dominate the summer and early autumn phytoplankton population, whereas during the winter and spring they are replaced by diatoms and green algae (Tilman et al., 1986). Nevertheless, cyanobacteria can be present and even dominant throughout the year (Chorus \& Bartram, 1999).

During the autumn of 1997 and the winter of 1998, severe rains occurred in the region. As a result, substantial amounts of nutrients were transported from the basin to the lake. Because the temperature and light in the S. Miguel island region are adequate for phytoplankton growth throughout the year and the nutritional conditions favour cyanobacteria development (Oliver \& Ganf, 2000), blooms occurred in 2000 . The term "bloom" is used here to mean a cell concentration greater than $20 \cdot 10^{3}$ cells/ml (Oliver \& Ganf 2000).

Eutrophication has been recognised as a water quality problem of increasing concern since the 1950s. Subsequently, the proliferation of cyanobacteria and cyanobacterial toxins were considered to be human health problems deriving from eutrophication because cyanobacteria that flourish in aquatic environments can produce a diverse range of toxins that present risks of illness and even mortality to humans and animals (Chorus \& Bartram, 1999). Cyanotoxins are secondary metabolites synthesised within the cells and include a wide variety of chemical compounds, primarily alkaloids and peptides (Sivonen \& Jones 1999; Kardinaal \& Visser, 2005; Falconer 2005), but also organophosphates and lipopolysaccharides (Chorus, 2001).

Freshwater cyanobacteria can produce microcystins and nodularins (both hepatotoxic cyclic peptides) and the cyclic guanidine alkaloid cylindrospermopsin as primary products. In addition, they can produce the neurotoxic alkaloids anatoxin-a, anatoxin-a(S) and saxitoxins, and lipopolysaccharides with pyrogenic properties (Chorus \& Bartram, 1999; Chorus 2001). Microcystins are produced by the most abundant cyanobacteria found in freshwaters worldwide. Several planktonic genera, such as Microcystis, Anabaena, Aphanizomenon and Planktothrixx, are considered potentially toxigenic. The concentrations of microcystins monitored in several lakes revealed highly variable concentrations $(\mu \mathrm{g} / \mathrm{l}$ and per unit seston dry weight-mg/ $\mathrm{kg}_{\mathrm{dw}}$ ) (Chorus \& Bartram, 1999; Chorus 2001; Codd et al. 2005; Falconer, 2005; Kardinaal \& Visser 2005).

The aim of this study is to report the occurrence of cyanobacterial blooms and microcystins in Lake Furnas (S. Miguel IslandAzores) and their variability in space and time over the past ten years.

\section{MATERIALS AND METHODS}

\section{Water sampling, physicochemical analysis and TSI}

The monitoring programme was initiated in February 2000 and included 38 sampling trips. Three of these trips were made in 2000, two in 2001 and four (winter, spring, summer and autumn) every year from 2002 through 2009. The water samples were always collected from a boat between 11 a.m. and 12 a.m., at one sampling point located in the middle of the lake at its deepest zone. Samples were collected with a Van Dorn-type device at the surface, $2.5 \mathrm{~m}, 5 \mathrm{~m}$ and $0.5 \mathrm{~m}$ above the sediments and transported in refrigerated polyethylene bottles (or in glass for samples destinated for the analysis of phosphorus 
and microcystins) to a laboratory. The samples were then analysed for physical and chemical parameters (nitrogen and phosphorus compounds and chlorophyl $a$ (Standard Methods, 1998)). The water temperature, $\mathrm{pH}$, dissolved oxygen, turbidity and conductivity were determined in situ with a multi-parameter meter (Horiba U 10, Horiba Ltd., Kyoto, Japan). Transparency was determined with a Secchi disc.

Carlson's trophic state index (TSI) based on chlorophyll $a$ (chl $a$ ) concentrations was calculated using the following equation (Carlson, 1977): TSI $=10\left(6-\log _{2} 7.7 / \mathrm{chl} a^{0.68}\right)$.

\section{Phytoplankton analyses}

Samples for phytoplankton analyses were obtained by mixing equal volumes of water collected at the four depths. One aliquot was placed in a polyethylene flask and preserved with a $1 \%$ Lugol solution. Phytoplankton identifications were performed with a Leica DML optical microscope. Utermöhl's method was used to determine the cell count (Lund et al. 1958).

\section{Analyses of microcystins}

The measurements of microcystins were made in the samples collected at the depths specified above from 2001 through 2009. The water samples were filtered through a glass fibre membrane (WhatmanGF/F, nominal pore size $\approx 0.7 \mu \mathrm{m}$ ). The filters with the biomass were kept frozen at $-18{ }^{\circ} \mathrm{C}$ prior to toxin extraction with methanol. The filtered samples were passed through C18 cartridges (Sep-Pak Waters Corporation), preconditioned with methanol and washed with water at a flow rate not exceeding $10 \mathrm{ml} / \mathrm{min}$. The cartridges were then eluted with $3 \mathrm{ml}$ methanol acidified with $0.1 \%$ TFA. The extracts were evaporated to dryness with a nitrogen flow. The residue was re-dissolved in $250 \mu \mathrm{l}$ methanol and centrifuged for $10 \mathrm{~min}$ at $10000 \mathrm{rpm}$. The filter discs were placed in glass beakers containing $20 \mathrm{ml}$ of methanol and allowed to extract for $24 \mathrm{~h}$ at $-4{ }^{\circ} \mathrm{C}$. The samples were evaporated under pressure at $40^{\circ} \mathrm{C}$ until they became dry. The residue was re-dissolved in $500 \mu \mathrm{l}$ methanol and
Table 1. Nitrogen, phosphorus and chlorophyll $a$ concentrations in the water of Lake Furnas during 2000-2009. Concentraciones del nitrógeno, fósforo y clorofila a en el agua de la Laguna Furnas en el periodo de 2000-2009.

\begin{tabular}{lcrrrr}
\hline & \multicolumn{4}{c}{$2000-2009$} \\
\cline { 3 - 6 } & & Aver. & Max. & Min. & $\mathrm{n}$ \\
\hline \multirow{2}{*}{ Nitrogen $\left(\mathrm{mg} \mathrm{N} / \mathrm{m}^{3}\right)$} & Total & 1474 & 2730 & 440 & 38 \\
& Inorganic & 316 & 940 & 80 & 38 \\
Total Phosphorus $\left(\mathrm{mg} \mathrm{P}^{3} / \mathrm{m}^{3}\right)$ & 49 & 93 & 17 & 38 \\
Chlorophyll- $a\left(\mathrm{mg} / \mathrm{m}^{3}\right)$ & 28 & 91 & 8 & 38 \\
TN:TP $\left(\mathrm{mg} \mathrm{N} / \mathrm{mg} \mathrm{P}^{3}\right)$ & 34 & 66 & 12 & 38 \\
\hline
\end{tabular}

centrifuged for $10 \mathrm{~min}$ at $10000 \mathrm{rpm}$. The centrifuged extracts were analysed using HPLC-UV with photodiode array detection using an Acclaim column $(4.6 \times 150 \mathrm{~mm} ; 3 \mu \mathrm{m})$. The different microcystins were separated and their peaks were identified based on UV absorption spectra analysis. The chromatographic signals (peaks) were quantified using microcystin LR standard calibration curves. The concentrations of total (unidentified) microcystins in each sample were expressed in equivalent units of microcystin LR (Lawton et al. 1994).

\section{RESULTS}

\section{Physicochemical measurements and TSI}

The water temperature at the surface of the lake at 11 a.m. ranged from $13{ }^{\circ} \mathrm{C}-14{ }^{\circ} \mathrm{C}$ during the late autumn and winter to $22^{\circ} \mathrm{C}-23^{\circ} \mathrm{C}$ during the summer. The transparency ranged from $0.2 \mathrm{~m}$ to $3.0 \mathrm{~m}$. The average transparency was $1.0 \mathrm{~m}$. The surface water $\mathrm{pH}$ ranged from 6.6 to 9.6.

The average nitrogen, phosphorus and chlorophyll $a$ (Chl $a$ ) concentrations in the water column and the TN:TP mass ratio are shown in Table 1.The inorganic nitrogen concentrations (the sum of ammonium, nitrite and nitrate) were quite variable, ranging from $80 \mathrm{mg} \mathrm{N} / \mathrm{m}^{3}$ to $940 \mathrm{mg} \mathrm{N} / \mathrm{m}^{3}$, with an average $\left(316 \mathrm{mgN} / \mathrm{m}^{3}\right)$ corresponding to a meso-eutrophic state. The total phosphorus concentrations (TP) ranged from $17 \mathrm{mg} \mathrm{P} / \mathrm{m}^{3}$ to $93 \mathrm{mg} \mathrm{P} / \mathrm{m}^{3}$. The average concentration of TP was $49 \mathrm{mg} \mathrm{P} / \mathrm{m}^{3}$, characteris- 


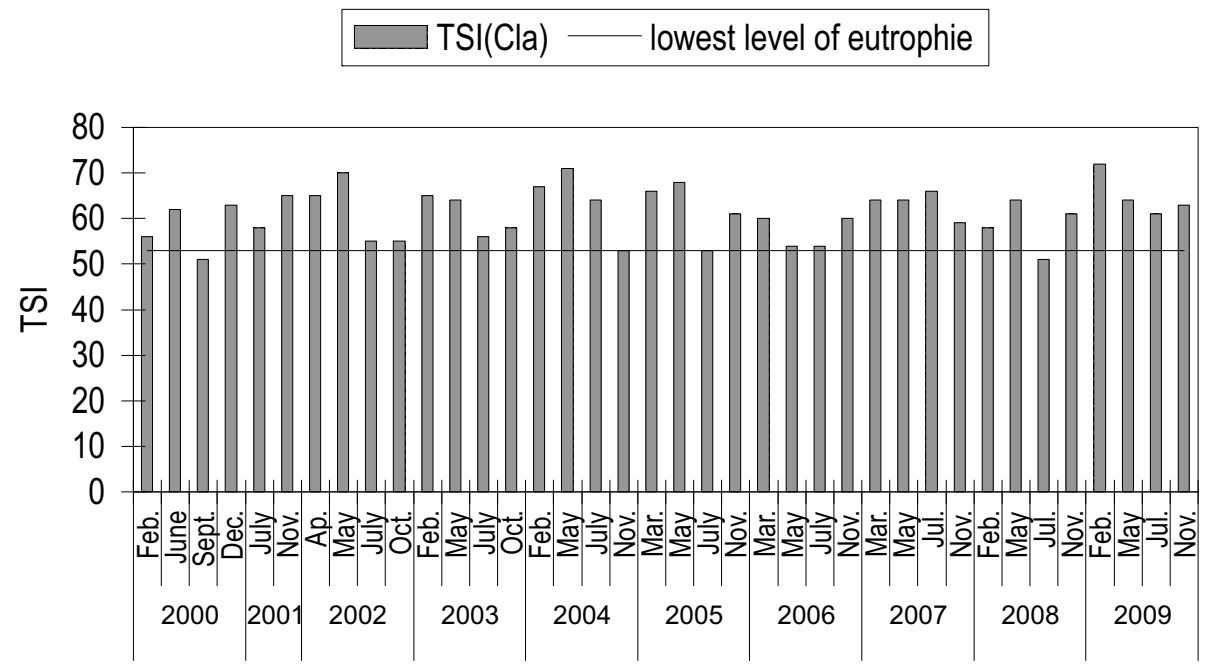

Figure 1. Chlorophyll (Carlson's Trophic State Index) in Lake Furnas (2000/2009). Índice de Estado Trófico de Carlson (IET) para la clorofila en la Laguna Furnas (2000/2009).

tic of eutrophic conditions (Vollenweider, 1968). According to OECD, 1982, the average concentration of TP and the concentration of Chl $a$ $\left(8 \mathrm{mg} / \mathrm{m}^{3}\right.$ to $91 \mathrm{mg} / \mathrm{m}^{3}$, with an average of $28 \mathrm{mg} / \mathrm{m}^{3}$ ) in Lake Furnas correspond to a eutrophic state. The maximum value of chlorophyll was already characteristic of a hypertrophic aquatic environment. The TN:TP mass ratio (mg N/mg P) ranged from 12 to 66, with an average of 34 .

The Carlson's Trophic State Index (TSI) average, based on Chl $a$ concentrations (Fig. 1), was
61, well above the eutrophic lower limit of 53 established by Kratzer \& Brezonic (1981). A minimum TSI of 51 was found only twice in 38 sampling trips. TSIs above 70 were detected three times. These findings indicate that the lake is eutrophic with a tendency to hypertrophy.

\section{Phytoplankton and cyanobacteria}

Total phytoplankton increased during the years of the study. The percentages of cyanobacte-

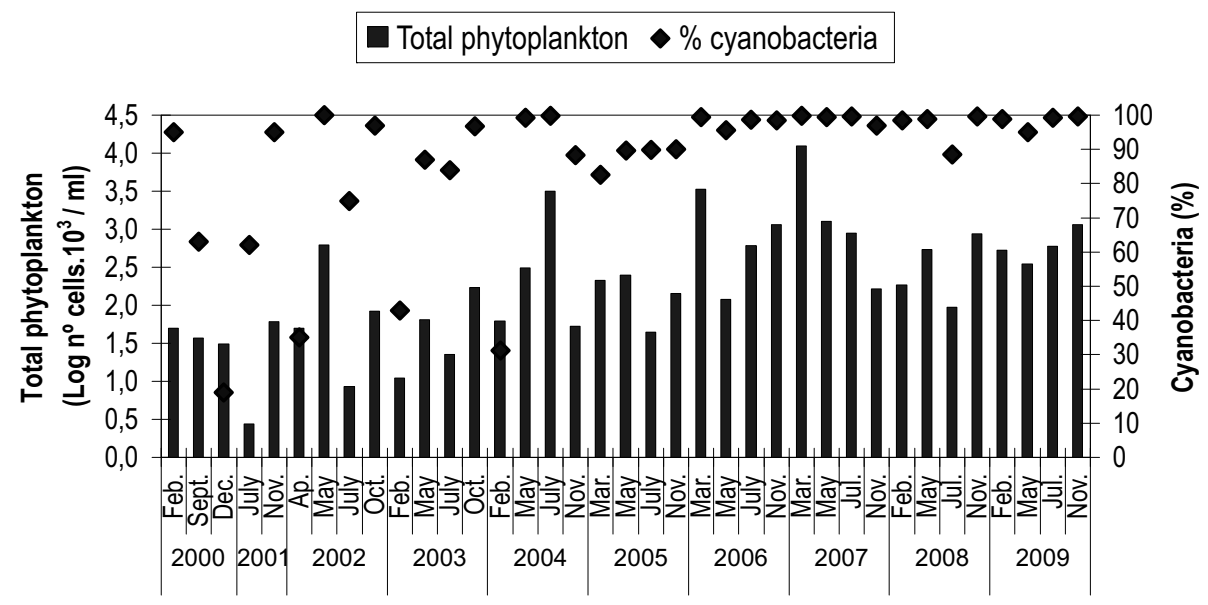

Figure 2. Total phytoplankton and relative percentage of cyanobacteria in Lake Furnas (2000/2009). Porcentaje relativa en total de fitoplancton y cianobacterias en la Laguna Furnas (2000/2009). 
ria remained greater than $90 \%$ after 2005 . The worst situations occurred during 2006 and 2007. Cyanobacteria represented approximately $99 \%$ of the total phytoplankton (Fig. 2) in almost every instance throughout these years.

The first cyanobacterial bloom was observed in February 2000. The bloom was caused by a proliferation of Microcystis aeruginosa $\left(45.2 \cdot 10^{3}\right.$ cells/ml). Subsequent to that event and until 2009 , this same species participated in 17 additional blooms, alone on five occasions and dominant in 12 when other cyanobacteria were also blooming. During 2006, the blooms of this species remained in the lake throughout the year. The situation reached its peak $\left(11.9 \cdot 10^{6}\right.$ cells $\left./ \mathrm{ml}\right)$ during the winter of 2007. One unidentified Microcystis sp. bloomed $\left(150.2 \cdot 10^{3}\right.$ cells $\left./ \mathrm{ml}\right)$ during the autumn of 2003. Two other Microcystis species, identified as $M$. flos-aquae and $M$. robusta, were detected in three additional blooms. $M$. robusta bloomed alone during autumn $2007\left(153.6 \cdot 10^{3}\right.$ cells $\left./ \mathrm{ml}\right)$ and bloomed during winter $2008\left(56.5 \cdot 10^{3}\right.$ cells/ $\mathrm{ml})$ with Woronichinia naegeliana $\left(121.2 \cdot 10^{3}\right.$ cells $/ \mathrm{ml})$. M. flos-aquae bloomed $\left(270.3 \cdot 10^{3}\right.$ cells/ml) with $M$. aeruginosa $\left(736.9 \cdot 10^{3}\right.$ cells/ $\mathrm{ml})$ and Coelosphaerium kuetzigianum $\left(204.8 \cdot 10^{3}\right.$ cells/ml) during autumn 2009 (Fig. 3).

The last mentioned cyanobacterium was first detected in November 2005 with a smaller cell density $\left(2.3 \cdot 10^{3}\right.$ cells $\left./ \mathrm{ml}\right)$. Its cell counts subse- quently increased to $78.0 \cdot 10^{3}$ cells $/ \mathrm{ml}$ during the summer and to $497.3 \cdot 10^{3}$ cells $/ \mathrm{ml}$ during the autumn of the same year. In March 2007, during the largest $M$. aeruginosa bloom, C. kuetzigianum $\left(395.0 \cdot 10^{3}\right.$ cells $\left./ \mathrm{ml}\right)$ was the second cyanobacterium blooming in the lake. $W$. naegeliana was the third, with $83.8 \cdot 10^{3}$ cells $/ \mathrm{ml}$. Subsequently, C. kuetzigianum occurred in five additional blooms, with cell densities varying from $44.7 \cdot 10^{3}$ cells $/ \mathrm{ml}$ to $610.6 \cdot 10^{3}$ cells $/ \mathrm{ml}$ and always combined with two or more cyanobacteria species that were also blooming.

W. naegeliana blooms began in the spring of $2003\left(53.0 \cdot 10^{3}\right.$ cells $\left./ \mathrm{ml}\right)$ when it was the only species of cyanobacteria blooming in the lake. Subsequently, this cyanobacterium was present in 16 more blooms, with cell densities that ranged from $31.3 \cdot 10^{3}$ cells $/ \mathrm{ml}$ to $3.18 \cdot 10^{6}$ cells $/ \mathrm{ml}$. The most significant bloom occurred in July 2004, when M. aeruginosa was also present. $W$. naegeliana was dominant in three more blooms $\left(121.0 \cdot 10^{3}\right.$ cells $/ \mathrm{ml}$ to $248.8 \cdot 10^{3}$ cells $\left./ \mathrm{ml}\right)$ in association with Microcystis spp., Anabaena sp. or C. kuetzigianum. It occupied second or third place in seven other blooms. During autumn 2004 $\left(47.0 \cdot 10^{3}\right.$ cells $\left./ \mathrm{ml}\right)$, spring and summer 2005 $\left(224.6 \cdot 10^{3}\right.$ cells $/ \mathrm{ml}$ and $31.3 \cdot 10^{3}$ cells $\left./ \mathrm{ml}\right)$ and winter and spring $2009\left(493.2 \cdot 10^{3}\right.$ cells $/ \mathrm{ml}$ and $322.1 \cdot 10^{3}$ cells $\left./ \mathrm{ml}\right)$, W. naegeliana was the only species of cyanobacteria blooming in the lake.

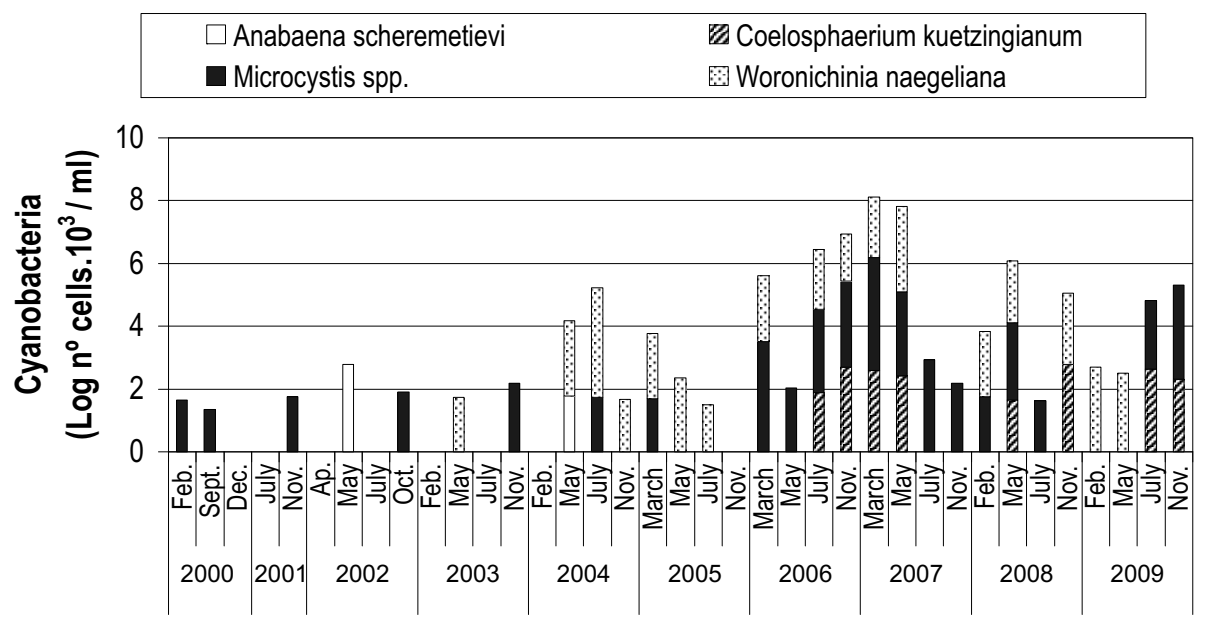

Figure 3. Relative abundance of the principal cyanobacterial species blooming in Lake Furnas (2000/2009). Abundancia relativa de cianobacterias causadoras de blooms en la Laguna Furnas (2000/2009). 
Anabaena spp. blooms were detected only twice. A. solitaria bloomed alone $\left(606.2 \cdot 10^{3}\right.$ cells $\left./ \mathrm{ml}\right)$ during May 2002 and A. scheremetievi $\left(58.8 \cdot 10^{3}\right.$ cells $/ \mathrm{ml}$ ) bloomed together with $W$. naegeliana $\left(248.8 \cdot 10^{3} \mathrm{cells} / \mathrm{ml}\right)$ during May 2004.

No correlations were found between the cell densities of cyanobacteria and nitrogen or phosphorus concentrations (inorganic and total forms) or with the TN:TP mass ratio. For example, Microcystis sp. blooms occurred at TN:TP mass ratio values from 12 to 57 and $W$. naegeliana blooms were detected at TN:TP values from 18 to 66 .

\section{Microcystins}

The detection of the blooms of 2000 was followed, beginning in 2001, by the analysis of microcystins in the water of Lake Furnas. A total of 129 samples were collected at several depths from 2001 through 2009. Microcystins in solution (extracellular) were detected in 25 samples $(19 \%)$. These microcystins were detected most often in samples from the lake's surface (11 samples) and less frequently in samples taken at a depth of $5 \mathrm{~m}$ ( 3 samples). Seven samples from the $2.5 \mathrm{~m}$ depth and five samples collected near the bottom were positive for dissolved microcystins.

The amount of dissolved microcystins (average concentrations in the water column) ranged from $0.05 \mu \mathrm{g}$ MC-LR equiv $_{1} / 1$ to $0.49 \mu \mathrm{g}$ MC$\mathrm{LR}_{\text {equiv }} /$ (Fig. 4). The highest single concentration $\left(1.95 \mu \mathrm{g}\right.$ MC-LR equiv $_{\text {eq }} / \mathrm{l}$ was detected in a sample collected $0.5 \mathrm{~m}$ above the sediments in May 2007 .

Intracellular microcystins (seston) were present in 108 samples $(84 \%)$ collected at several depths. Their concentration increased during 2008 and 2009. After 2005, all the samples analysed contained intracellular microcystins. The samples from the lake's surface normally contained higher concentrations of intracellular microcystins, but these compounds were also present in samples from other depths.

The most frequently observed concentrations were less than $20 \mu \mathrm{g}$ MC-LR equiv $/ 1$. However, during the winter of 2009 , a value of $154.5 \mu \mathrm{g}$ MC$\mathrm{LR}_{\text {equiv }} /$ was observed in a sample collected from the surface of the lake during a bloom of $W$. naegeliana $\left(493.2 \cdot 10^{3}\right.$ cell $\left./ \mathrm{ml}\right)$. At that time, A. sheremetievi $\left(9.5 \cdot 10^{3}\right.$ cells $\left./ \mathrm{ml}\right)$, Aphanocapsa delicatissima $\left(9.2 \cdot 10^{3}\right.$ cells $\left./ \mathrm{ml}\right)$, Chroococcus dispersus $\left(6.6 \cdot 10^{3}\right.$ cells $\left./ \mathrm{ml}\right)$ and Lyngbya sp. $\left(6.4 \cdot 10^{3}\right.$ cells $\left./ \mathrm{ml}\right)$ were also recorded, but none of these four species were blooming. On several occasions in this lake, the occurrence of $W$. naegeliana could be related to the detection of microcystins. During winter 2004, this bacterium was the only species of cyanobacteria found in the lake. Its cell density was lower

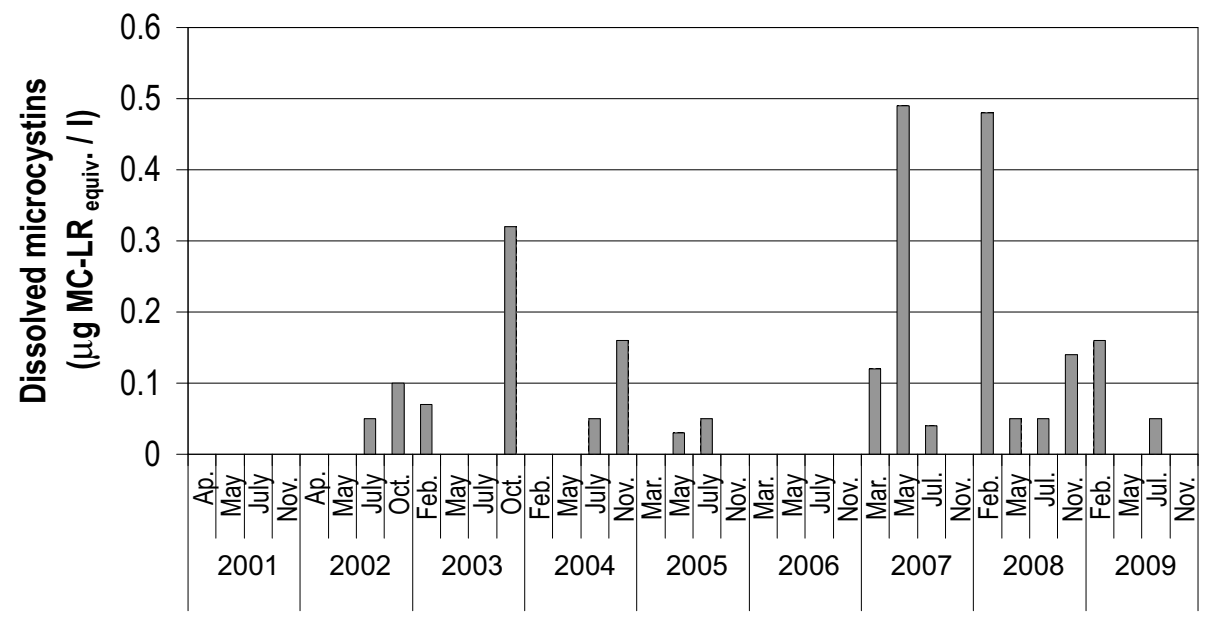

Figure 4. Concentrations of dissolved microcystins ( $\mu \mathrm{g}$ MC-LR equiv/l) detected in Lake Furnas samples collected from 2001 through 2009. Concentraciones de microcistinas disueltas ( $\mu \mathrm{g} M C-L R_{\text {equiv }} /$ ) detectadas en muestras de la Laguna Furnas cogidas entre 2001 y 2009. 
than that of a bloom $\left(19.4 \cdot 10^{3}\right.$ cells $\left./ \mathrm{ml}\right)$, and intracellular microcystins were detected at concentrations of $2.85 \mu \mathrm{g} \mathrm{MC-LR}$ equiv $/ 1$ to $4.33 \mu \mathrm{g}$

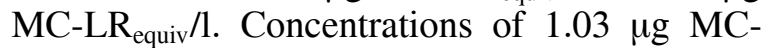

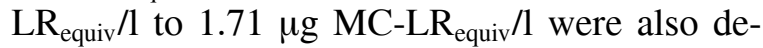
tected during the autumn of the same year when W. naegeliana $\left(47.0 \cdot 10^{3}\right.$ cells $\left./ \mathrm{ml}\right)$ was blooming alone in the lake. The other cyanobacterium present was Phormidium mucicola, occurring at a very low density $\left(0.02 \cdot 10^{3}\right.$ cells $\left./ \mathrm{ml}\right)$. $W$. naegeliana was also the only cyanobacterium blooming during spring $2005\left(224.6 \cdot 10^{3}\right.$ cells $/ \mathrm{ml}$ ) and intracellular microcystins were detected in the water column at concentrations ranging from $0.56 \mu \mathrm{g} \mathrm{MC}-\mathrm{LR}_{\text {equiv }} / 1$ to $2.38 \mu \mathrm{g}$ $\mathrm{MC}-\mathrm{LR}_{\text {equiv }} / \mathrm{l}$. Other cyanobacteria were also identified at the same time, but their densities were very low (A. scheremetievi $-0.09 \cdot 10^{3}$ cells/ml, Aphanocapsa elachista and Oscillatoria sp. - both with $<0.01 \cdot 10^{3}$ cells $/ \mathrm{ml}$ ). These results indicate that the $W$. naegeliana strain found in this Azorean lake is toxigenic.

No correlations were found between the average concentrations of total microcystins in the water column and the cell densities of cyanobacteria (Fig. 5). In fact, the highest amounts of microcystins did not correspond to the largest blooms of cyanobacteria. Moreover, no correlations were found between the densities of individual species blooming in the lake and the concentrations of microcystins.

The amounts of microcystins produced by cyanobacteria, expressed based on seston dry weight, were determined only after 2003. The average concentrations in the water column varied from 0 to $6060 \mathrm{mg} \mathrm{MC-LR}$ equiv $/ \mathrm{kg}_{\mathrm{dw}}$ and showed an increase during 2008 and 2009 (Fig. 6). The highest concentration (9737 mg MC-LR $\mathrm{equiv}_{\mathrm{v}} / \mathrm{kg}_{\mathrm{dw}}$ ) was recorded in a sample collected from the surface of the lake in May 2009 during a bloom of $W$. naegeliana $\left(322.0 \cdot 10^{3}\right.$ cells $\left./ \mathrm{ml}\right)$. C. kuetzigianum $\left(8.5 \cdot 10^{3}\right.$ cells $\left./ \mathrm{ml}\right)$ was also present, and other cyanobacteria were present at densities less than $1.0 \cdot 10^{3}$ cells $/ \mathrm{ml}$. At that time, samples from 2.5 $\mathrm{m}$ and $5 \mathrm{~m}$ depths also contained high amounts of microcystins $\left(6216 \mathrm{mg} \quad \mathrm{MC}-\mathrm{LR}_{\text {equiv }} / \mathrm{kg}_{\mathrm{dw}}\right.$ and $8070 \mathrm{mg} \mathrm{MC}-\mathrm{LR}_{\text {equiv }} / \mathrm{kg}_{\mathrm{dw}}$, respectively). In samples from $M$. aeruginosa blooms, the concentrations of microcystins ranged from $86 \mathrm{mg}$ $\mathrm{MC}-\mathrm{LR}_{\text {equiv }} / \mathrm{kg}_{\mathrm{dw}}$ to $1171 \mathrm{mg} \mathrm{MC}-\mathrm{LR}_{\text {equiv }} / \mathrm{kg}_{\mathrm{dw}}$. The highest values were recorded during spring and summer 2008. The concentrations of microcystins per unit seston dry weight were not correlated with the cell densities of cyanobacteria.

Total MC $\bullet$ Cyanobacteria

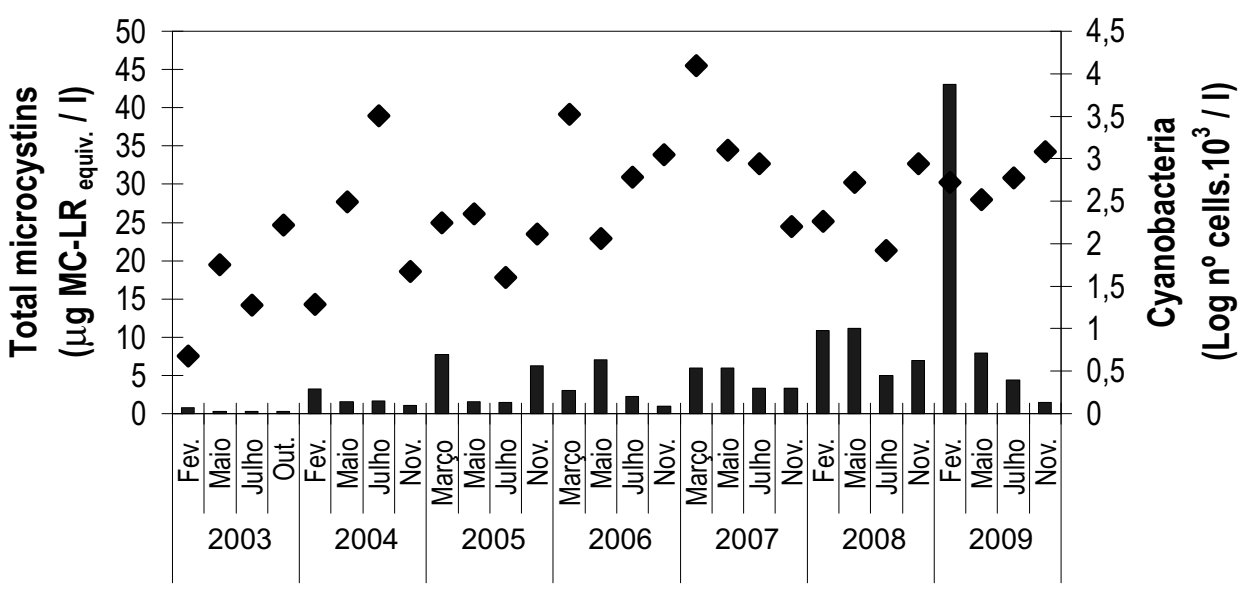

Figure 5. Average concentrations of total microcystins in the water column $\left(\mathrm{MC}-\mathrm{mg} \mathrm{MC}-\mathrm{LR}_{\text {equiv }} / \mathrm{m}^{3}\right)$ vs. cyanobacterial cell densities in Lake Furnas (2001/2009). Concentraciones medias de microcistinas totales en la columna de agua (MC-mg MC$L R_{\text {equiv }} / \mathrm{m}^{3}$ ) vs. densidades celulares de cianobacterias en la Laguna Furnas (2001/2009). 
Intracellular MC / biomass dry weight

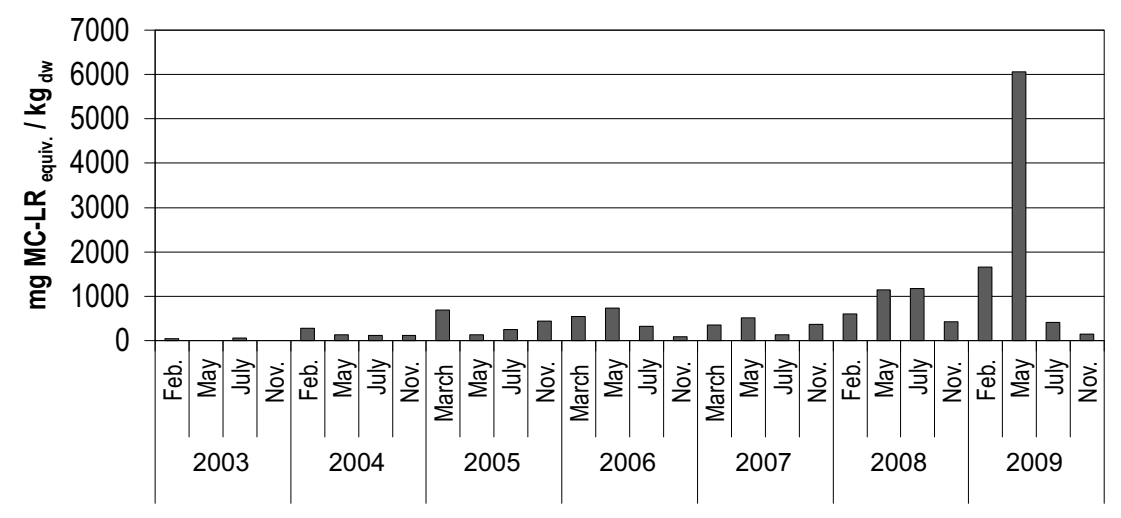

Figure 6. Average concentrations of intracellular microcystins in the water column per unit seston dry weight (mg MC-LR equiv $\left./ \mathrm{kg}_{\mathrm{dw}}\right)$ in Lake Furnas (2003/2009). Concentraciones medias de microcistinas intracelulares por unidad de peso seco de seston ( $m g$ MC-LR $R_{\text {equiv }} / \mathrm{kg}_{\text {ps }}$ ) en la Laguna Furnas (2003/2009).

\section{DISCUSSION}

Although the process of eutrophication in Lake Furnas has been recognised since 1989, blooms of cyanobacteria only began to occur in the lake in 2000. These blooms followed the severe rains of $1997 / 1998$ on the island of S. Miguel. Until 2004, blooms of cyanobacteria were primarily detected between spring and autumn. This pattern is similar to that known from many countries of the European continent, such as Continental Portugal (Vasconcelos, 1994) and Spain (Quesada et al., 2004; Moreno et al., 2005), where blooms can occur in rivers and reservoirs, especially during late summer and autumn. After 2004, cyanobacteria blooms occurred regularly in Lake Furnas, even during winter, due to high nutrient availability and also to environmental conditions. In fact, this study shows that the mild weather of the Azorean Archipelago favours the proliferation of cyanobacteria throughout the year. Previously, the occurrence of blooms of cyanobacteria was also reported from Lake SeteCidades, a mesotrophic lake located in the northwest zone of the island. These blooms lasted from winter to autumn (Santos et al., 2005).

The blooms occurring in Lake Furnas were dominated primarily by Chroococcales (Microcystis spp., especially $M$. aeruginosa, C. kuetzingianum and W. naegeliana). Blooms of An- abaena sp. (Nostocales) only occurred twice. The highest cell density of cyanobacteria occurred during winter $2007\left(12.3 \cdot 10^{6}\right.$ cells $\left./ \mathrm{ml}\right)$, in a bloom dominated by $M$. aeruginosa $\left(11.9 \cdot 10^{6}\right.$ cells $/ \mathrm{ml})$. In this bloom, $C$. kuetzingianum $\left(395 \cdot 10^{3}\right.$ cells $\left./ \mathrm{ml}\right)$ was subdominant and $W$. naegeliana $\left(84 \cdot 10^{3}\right.$ cells $\left./ \mathrm{ml}\right)$ was also present. Cell densities as high as these were previously reported by several authors, e.g. Moreno et al., 2005 (Vitonogales and Valdelacalzada in Guadiana River, Spain) and Pawlik-Skowronska et al., 2004 (lakes in Poland).

The absence of a significant relationship between cyanobacterial cell densities and nutrient concentrations in Lake Furnas indicates that nitrogen and phosphorus were always plentiful in the lake during the period of investigation. In fact, inorganic nitrogen concentrations ranged from 80 to $940 \mathrm{mg} \mathrm{N} / \mathrm{m}^{3}$. These very high values also explained the dominance of cyanobacterial species that are not diazotrophic. Even the blooms of the nitrogen-fixing Anabaena spp. occurred at inorganic nitrogen concentrations of $250 \mathrm{mg} / \mathrm{m}^{3}$ and $150 \mathrm{mg} / \mathrm{m}^{3}$, higher than the threshold value of $50-100 \mathrm{mg} / \mathrm{m}^{3}$ considered to be the limit below which nitrogenase activity is induced (Oliver \& Ganf, 2000). These results also suggest that TN:TP ratios are not important for determining cyanobacterial dominance, as previously concluded by several authors cited 
in Oliver \& Ganf (2000). Smith (1983) concluded from a survey of data on 17 lakes that bloomforming cyanobacteria will tend to dominate if the TN:TP mass ratio is less than 29. However, one half of the 30 cyanobacterial blooms in Lake Furnas reported here were associated with TN:TP mass ratios ranging from 29 to 66 . The other half of these blooms was associated with TN:TP values varying from 12 to 29 .

All the cyanobacteria blooming in Lake Furnas are found worldwide (Fristachi \& Sinclair 2008) and are potentially toxigenic (Lawton et al., 1999; Whitton \& Potts, 2000; Chorus, 2001; Falconer, 2004; Hudnell (ed.), 2008). The toxigenicity of the cyanobacteria found in Lake Furnas was confirmed by the findings that $19 \%$ of 129 samples collected in the lake at several depths, from 2001 through 2009, contained soluble microcystins and $84 \%$ of the samples revealed the presence of intracellular microcystins. These results are consistent with several reports from European countries. These reports showed that $61 \%$ to $90 \%$ of the samples collected from several water bodies during the 1980s and 1990s were toxic (Quesada et al, 2004).

The average concentrations of extracellular microcystins ranged from $0.05 \mu \mathrm{g}$ MC-LR $\mathrm{R}_{\text {equiv }} / 1$ to $0.49 \mu \mathrm{g} \mathrm{MC}_{-} \mathrm{LR}_{\text {equiv }} / \mathrm{l}$, values similar to those found in the water of Lake Sete-Cidades (Santos et al., 2005). These results are in accordance with several surveys (Chorus, 2001) and enable us to conclude that extracellular microcystins are seldom found. Their concentrations rarely exceed $1 \mu \mathrm{g} / \mathrm{l}$, and substantial concentrations are exceptional and transitory. The highest concentration of dissolved microcystins $\left(1.95 \mu \mathrm{g}\right.$ MC-LR $\left.\mathrm{R}_{\text {equiv }} / \mathrm{l}\right)$ was detected in a bottom sample collected during May 2007 and can be related to a substantial accumulation of dead cyanobacteria in the sediments, after the significant winter bloom caused by the three cyanobacterial species $M$. aeruginosa, C. kuetzingianum and W. naegeliana. The dead biomass of these cyanobacteria was still releasing toxins to the water four months after the bloom reached its highest density.

After 2005, intracellular microcystins were detected in all samples. Their concentrations increased during 2008 and 2009. The most frequent water column average values were less than $20 \mu \mathrm{g}$ $\mathrm{MC}-\mathrm{LR}_{\text {equiv }} / \mathrm{l}$, but a concentration of $154.5 \mu \mathrm{g}$ $\mathrm{MC}-\mathrm{LR}_{\text {equiv }} / \mathrm{l}$ was recorded in the 2009 winter surface sample, during a bloom of $W$. naegeliana $\left(493.2 \cdot 10^{3}\right.$ cells $\left./ \mathrm{ml}\right)$. Even higher concentrations of total microcystins (greater than $500 \mu \mathrm{g} / \mathrm{l}$ ) were previously found in 1997 in the Spanish part of the Tajo Basin (Gordo et al., 1999 cited by Quesada et al., 2004).

In the same 2009 winter sample, the amount of microcystins per unit seston dry weight was also very high (9737 mg MC-LR $\mathrm{Mquiv}_{\text {e }} / \mathrm{kg}$ ). In comparison, maximal values reported from Germany, Czech Republic and Korea were from $1500 \mathrm{mg} / \mathrm{kg}$ to $5800 \mathrm{mg} / \mathrm{kg}$ and the highest value (7100 mg/kg) was recorded in Portugal (Chorus, 2001). More recently, Willame et al., 2005, reported that $2231 \mathrm{mg} / \mathrm{kg}$ was the highest concentration found in a study of lakes of Belgium and Luxembourg. This value was found in a sample of a bloom dominated by $W$. naegeliana. Grabowska \& Pawlik-Skowronska (2008) also reported $7827 \mathrm{mg} / \mathrm{kg}$ as the maximum concentration found in a reservoir in the northeast region of Poland. However, this value was associated with an increase of Oscillatoriales in the water body and a simultaneous decrease of Chroococcales. In Lake Furnas, where similarly high amounts of microcystins were recorded, Chroococcales were almost always dominant.

The local authorities are concerned about the results presented here, especially in view of the progressive increase of the concentrations of microcystins over time. Nevertheless, several measures are already being taken in the basin of the lake to prevent the advance of eutrophication, and it is expected that the cyanobacteria blooms will diminish.

\section{ACKNOWLEDGEMENTS}

This research was supported by the Environment Secretary of Azores Regional Government and was performed with the participation of the Environmental Science Department of the New University of Lisbon.

The authors thank Prof. António Rodrigues, algae specialist from the New University of Lis- 
bon, and Drs. Maria Isabel Andrade and Leonor Cabeçadas, experts from the Portuguese Environment Agency, for phytoplankton analysis.

\section{REFERENCES}

APHA-AWWA-WEF. 1998. Standard Methods for the Examination of Water and Wastewater, $20^{\text {th }}$ Ed., USA. 1031 pp.

CARLSON, R. E. 1977. A trophic state index for lakes. Limnology and Oceanography, 22: 361369.

CHORUS, I. \& J. BARTRAM. (eds.) 1999. Toxic Cyanobacteria in Water. World Health Organization, E \& FN Spon, London, 416 pp.

CHORUS, I. (ed.) 2001. Cyanotoxins: Occurrence, causes and consequences. Springer-Verlag, Berlin Heidelberg, $357 \mathrm{pp}$.

CODD, G. A., J. LINDSAY, F. M. YOUNG, L. F. MORRISON \& J. S. METCALF. 2005 Harmful Cyanobacteria. From mass mortalities to management measures. In: Harmful Cyanobacteria. J. Huisman; H. C. P. Matthijs \& P. M. Visser, (eds.): 1-23. Aquatic Ecology Series, Vol. 3. Springer, The Netherlands.

COOKE, G. D., E. B. WELCH, S. A. PETERSON \& P. R. NEWROTH. 1993. Restoration and Management of Lakes and Reservoirs, $2^{\text {nd }}$ Ed. Lewis Publishers, CRC Press, Boca Raton, Florida, USA. $548 \mathrm{pp}$.

FALCONER, I. R. 2005. Cyanobacterial Toxins of Drinking Water Supplies. CRC Press, USA, $279 \mathrm{pp}$.

FRISTACHI, A. \& J. L. SINCLAIR. 2008. Occurrence of Cyanobacterial Harmful Algal Blooms Workgroup Report. In: Cyanobacterial Harmful Algal Blooms-State of the Science and Research Needs. H. K. Hudnell (ed.):45-103, Springer, USA.

GRABOWSKA, M. \& B. PAWLIK-SKOWRONSKA. 2008. Replacement of chroococcales and nostocales by oscillatoriales caused a significant increase in microcystin concentrations in a dam reservoir. Oceanological and Hydrobiological Studies. International Journal of Oceanography and Hydrobiology, 23(4): 23-33.

HUDNELL, H. K.(Ed.) 2008. Cyanobacterial Harmful Algal Blooms. State of the Science and Research Needs. Springer, USA, 949 pp.
INOVA 1996. Análise das Águas das Lagoas da Região Autónoma dos Açores-Technical Report, S. Miguel-Açores. 547 pp.

INOVA 1998. Análise das Águas das Lagoas da Região Autónoma dos Açores-Technical Report, S. Miguel-Açores. 580 pp.

KARDINAAL, W. E. A. \& P. M. VISSER. 2005. Dynamics of cyanobacterial toxins. Sources of variability in microcystin concentrations. In: Harmful Cyanobacteria. J. Huisman, H. C. P. Matthijs, \& P. M. Visser, (eds.): 41-63. Aquatic Ecology Series, Vol. 3. Springer, The Netherlands.

KRATZER, C. R. \& P. L. BREZONIK. 1981. A Carlson-type trophic state índex for nitrogen in Florida lakes. Water Resources Bulletin, 17: 713717

LAWTON, L. A., C. EDWARDS \& G. A. CODD. 1994: Extraction and High-performance Liquid Chromatographic Method for the Determination of Microcystins in Raw and Treated Waters, Analyst, 119: 1525-1530.

LAWTON, L. A., B. MARSALEK, J. PADISÁK \& I. CHORUS. 1999. Determination of Cyanobacteria in the Laboratory, In: Toxic Cyanobacteria in Water: A guide to their Public Health Consequences, Monitoring and Management, I. Chorus \& J. Bartram (eds.): 348-367. Spon, London, U.K.

LUND, J. W. G., C. KIPLING \& E. D. LE CREN. 1958: The inverted microscope method of estimating algal numbers and the statistical basis of estimation by counting. Hydrobiologia, 11: 143-170.

MORENO, I., G. REPETTO, E. CARBALLAL, A. GAGO \& E. CAMEÁN. 2005. Cyanobacteria and microcystins occurrence in the Guadiana River (SW Spain), Intern. J. Environ. Anal. Chem., 85(7): 461-474.

MUR, L. R., O. M. SKULBERG \& H. UTKILEN. 1999. Cyanobacteria in the Environment, In: Toxic Cyanobacteria in Water: A guide to their Public Health Consequences, Monitoring and Management, I. Chorus \& J. Bartram (eds.): 15-40. Spon, London, U.K.

OECD. 1982. Eutrophication of Waters: Monitoring, Assessment and Control. Paris: OECD., 154 pp.

OLIVER, R. L. \& G. G. GANF. 2000 Freshwater Blooms. In: The Ecology of Cyanobacteria. Their Diversity in Time and Space. B. A. Whitton \& M. Potts (eds.): 150-183. Kluwer Academic Publishers, Netherlands 
PAWLIK-SKOWRONSKA, B., T. SKOWRONSKI, J. PIRSKEL \& A. ADAMCZYK. 2004. Relationship between Cyanobacterial Bloom Composition and Anatoxin-A and Microcystin Occurrence in the Eutrophic Dam Reservoir (SE Poland), Polish Journal of Ecology, 52(4): 479-490.

PORTEIRO, J. \& H. CALADO. (1998): Plano de Ordenamento da Bacia Hidrográfica da Lagoa das Furnas, $1^{a}$ Fase, Estudos de CaracterizaçãoVol. II, 174 pp., Universidade dos Açores, Departamento de Biologia, Secção de Geografia, Ponta Delgada, Açores. 129 pp.

QUESADA, A., D. SANCHIS \& D. CARRASCO. 2004. Cyanobacteria in Spanish reservoirs. How frequently are they toxic?, Limnetica, 23 (1-2): 109-118.

RODRIGUES, A. M. F., M. C. R. SANTOS, F. SANTANA \& P. SOBRAL. 1993. Phytoplankton and Eutrophication of Furnas Caldera (S. Miguel Island/Azores). I Simpósio Fauna e Flora das Ilhas Atlânticas, Boletim do Museu Municipal do Funchal, Supl. No 4: 637-649.

SANTOS, M. C. R., F. J. P. SANTANA, A. M. F. RODRIGUES \& M. P. SOBRAL. 1991. Controlo da Eutrofização das Lagoas de S. Miguel (Açores). Parte II-A Lagoa das Furnas, Technical Report, D.C.E.A., Universidade Nova de Lisboa, 136 pp.

SANTOS, M. C. R.., A. M. F. RODRIGUES, M. P. SOBRAL \& F. J. P. SANTANA. 1992. A Eutrofização de meios lacustres. Lagoas das Sete-Cidades e Lagoa das Furnas, A. R. Pires, C. Pio, C. Bóia e T. Nogueira (Eds.), Procc. $3^{a}$ Conferência Nacional sobre a Qualidade do Ambiente: 217-228. Comissão de Coordenação da Região Centro, Coimbra.

SANTOS, M. C. R., D. M. PACHECO, F. J. P. SANTANA \& A. M. F. RODRIGUES. 2004. A Eutrofização das Lagoas das Sete-Cidades e Furnas (S. Miguel-Açores). Análise evolutiva entre 1988 e 2002., Actas do $7^{\circ}$ Congresso da Água,
Associação Portuguesa dos Recursos Hídricos, LNEC, Lisboa, 8 a 12 de Março. 16 pp.

SANTOS, M. C. R., D. M. PACHECO, F. J. P. SANTANA \& H. MUELLE. 2005. Cyanobacteria blooms in Sete-Cidades lake (S. Miguel IslandAzores), Algological Studies, 117: 393-406.

SIVONEN, K. \& G. J. JONES. 1999. Cyanobacterial Toxins. In: Toxic Cyanobacteria in Water: A guide to their Public Health Consequences, Monitoring and Management, I. Chorus \& J. Bartram (eds.): 41-111 Spon, London, U.K.

SMITH, V. H. (1983): Low nitrogen to phosphorus ratio favour dominance by bluegreen algae in lake phytoplankton. Science, 221: 669-671.

TILMAN, D., R. KIESLING, R. STERNER, S. S. KILHAM \& F. A. JOHNSON. 1986. Green, bluegreen and diatom algae: taxonomica differences in competitive ability for phosphorus, silicon and nitrogen. Archiv fur Hydrobiologie, 106, 473-85.

VASCONCELOS, V. M. 1994. Toxic cyanobacteria (blue-green algae) in Portuguese freshwaters. Arch. Hydrobiologie, 130: 439-451.

VOLLENWEIDER, R. A. 1968. Water Management Research: Scientific Fundamentals of the Eutrophication of Lakes and Flowing Waters, Technical Report DAS/CSI/68.27, OECD, Paris. 159 pp.

VOLLENWEIDER, R. A. 1976. Advances in defining critical loading levels for phosphorus in lake eutrophication. Memorie dell'Istituto Italiano di Idrobiologia, 33, 53-83.

WILLAME, R., T. JURCZAK, J. F. IFFLY, T. KULL, J. MERILUOTO \& L. HOFFMANN. 2005. Distribution of hepatotoxic cyanobacterial blooms in Belgium and Luxembourg, Hydrobiolo., 551: 99117.

WHITTON, B. A. \& M. POTTS. (Eds.) 2000. The Ecology of Cyanobacteria. Their Diversity in Time and Space. Kluwer Academic Publishers, Netherlands. $669 \mathrm{pp}$. 